\title{
Student voice and influence on employability in Australian higher education
}

\author{
Lisa Andrewartha ${ }^{1}$ and Andrew Harvey ${ }^{1}$ \\ l.andrewartha@latrobe.edu.au; andrew.harvey@latrobe.edu.au
}

${ }^{1}$ La Trobe University

\begin{abstract}
Higher education institutions are increasingly focussed on improving the capacity and potential of their graduates to gain employment. Attempts to develop employability skills through both mainstream and extra-curricular activities create new demands and expectations for students. Despite these demands, little attention has been given to student voice and influence in the employability sphere. Furthermore, the specific role of student unions in improving employability has been marginalised in Australian research. The research reported in this paper involved conducting a national survey of student groups and a comprehensive desktop review to capture student perspectives and investigate strategies to improve employability. From the research five broad student-centred approaches were identified: providing input into university employability strategies; placing students in positions of leadership and responsibility; delivering careers services; managing clubs and societies; and advocating for students from equity groups who have relatively poor completion rates and/or graduate outcomes. The findings are discussed and recommendations targeted to higher education institutions and student unions are provided.
\end{abstract}

Key words: higher education; graduate employability; student unions; student voice; student equity

\section{Introduction}

Universities are increasingly focussed on developing strategies to improve the capacity and potential of their graduates to gain employment. At the same time, students from diverse backgrounds are participating in higher education in unprecedented numbers. A major national research study was undertaken to investigate a range of higher education employability strategies and their accessibility and relevance to diverse student cohorts (Harvey, Andrewartha, Edwards, Clarke, \& Reyes, 2017). One component of this project focussed on student voice and influence. The aim was to explore the unique role that student unions can play in promoting employability and to capture previously unheard student perspectives on the employability arena. To achieve these aims, a national survey of student representatives and a desktop review of student union structures and activities were conducted. While terminology differs across institutions and nations, the term 'student unions' is used broadly in this article to refer to all student-led organisations that represent students and advocate for their rights and interests, including guilds and associations. The term 'student representatives' is used collectively to refer to students holding positions within student unions, including presidents, vice-presidents, general secretaries, and equity officers. A major role of student representatives is to speak to the views and interests of the wider student population, making them well placed to reflect the student voice. 
This article begins by providing the national context of the rise of employability within higher education and outlining disparities in graduate outcomes. The growing importance of extracurricular activities, many of which are managed by student unions, is then explored. Subsequently, the findings from the original research are presented. These findings underlined the important role that student unions can play in improving student employability, particularly through student leadership roles and clubs and societies. Of particular interest was the finding that students were mostly marginalised from the development of university employability strategies, despite holding strong views and expressing a willingness to contribute. Student representatives were specifically concerned about the employment outcomes of students from equity groups and felt that universities could do more in this space. Finally, the implications of the research for universities and students unions are discussed, highlighting the broad need for cultural change to redress unequal graduate outcomes.

\section{Context}

Employability is central to the modern mission of Australian higher education. Employability can be loosely defined as the capacity and potential of a graduate to gain employment (Yorke, 2006). Traditional conceptions of employability have focussed on providing graduates with skills sought by employers, including both discipline-specific skills and transferable skills (Bridgstock, 2009). More recent conceptions of employability acknowledge the additional skills and attributes that graduates need in order to sustain employment in increasingly competitive and rapidly changing labour markets. Bridgstock (2009), for example, stresses the importance of career management skills. She argues that graduates need to proactively navigate the working world and successfully manage the career building process, based on attributes such as lifelong learning and adaptability (p. 35). Bennett, Richardson, and MacKinnon (2016) also emphasise the importance of adaptability, innovation, and life-long critique of self and career to achieve sustained employment (p. 26). It should be noted that employment is distinct from employability, which refers specifically to the acquisition of a job (Yorke, 2006). A graduate with a high level of employability might not secure employment for a range of reasons, such as labour market factors and personal circumstances. As employability is inherently more difficult to measure than employment, short-term graduate employment outcomes have often been used as a proxy measure.

Australian universities are facing increasing pressure to demonstrate the employability of their graduates. A major national research study highlighted the prioritisation of employability in higher education (Harvey et al., 2017). This project found that approximately three quarters of universities considered employability within their strategic plans, and approximately half of the universities had a member of senior management with specific responsibility for employability (Harvey et al., 2017). At the same time, information on graduate employment outcomes is becoming more accessible to prospective students. The Quality Indicators of Learning and Teaching (QILT) website was launched in 2015 and allows students to compare graduate employment outcomes across institutions and disciplines (QILT, 2017). Since 2016, the QILT suite of surveys also includes a new national measure of employer satisfaction, which captures the satisfaction of workplace supervisors with the technical and generic skills of recent graduates. It is clear that employers expect graduates to be both versatile and technically skilled in today's competitive labour market. A recent analysis of job vacancy advertisements found that the most common requirements of employers were: communication skills; teamwork skills; job specific or technical skills; experience; and interpersonal skills (Messum, Wilkes, Peters, \& Jackson, 2016). In this environment, university-industry collaboration is becoming more pervasive as a means of improving graduate employability (Tran, 2016). Performance-based funding is also rising. Under the Australian Government's (2017) proposed higher education reform, a proportion of university funding will be dependent on performance measures such as completion rates and employment outcomes. 
As graduate outcomes are increasingly scrutinised, it is important to address persistent inequities. The Australian higher education equity framework identifies six equity groups: people from low socio-economic status (SES) backgrounds; people from regional and remote areas; people from non-English speaking backgrounds (NESB); Aboriginal and Torres Strait Islanders (also referred to as Indigenous peoples); people with a disability, and; women in non-traditional areas, such as science, technology, engineering and mathematics (Department of Education, Employment and Training, 1990). Despite strong participation growth, most equity groups are still under-represented in higher education compared to their population share (Harvey, Burnheim, \& Brett, 2016). Low SES, regional, and Indigenous students also have lower completion rates than their peers (Department of Education and Training, 2016).

For equity students who are retained through to graduation, there are clear patterns in employment outcomes. Graduates from non-English speaking backgrounds and graduates with a disability have particularly poor employment outcomes (Brett, 2016; Graduate Careers Australia [GCA], 2015; Li, Mahuteau, Dockery, Junankar \& Mavromaras, 2016; Mestan \& Harvey, 2014). Low SES and regional graduates remain under-represented in the most competitive fields that attract the highest salaries (Centre for the Study of Higher Education, 2008) and in post-graduate study (Burnheim \& Harvey, 2016; Harvey \& Andrewartha, 2013). Indigenous students remain severely under-represented in higher education. While Indigenous graduates have positive employment outcomes overall (GCA, 2015; Edwards \& Coates, 2011), they earn less than non-Indigenous graduates (Richardson, Bennett, \& Roberts, 2016). Female graduates from many science, technology, engineering and mathematics disciplines are paid lower salaries than their male counterparts (GCA, 2015). Given these trends, it is crucial for universities to consider equity issues within their employability strategies and initiatives.

One way in which students can develop their employability skills is by participating in extracurricular activities alongside their degree study. Research suggests that employers value extra-curricular participation as a means of distinguishing between similarly qualified graduates and providing a potential indication of cultural fit, social skills, and communication skills (Stuart, Lido, Morgan, Solomon, \& May, 2011). There has been a recent trend towards formally recognising extra-curricular participation through modified or supplemented academic transcripts and/or within student portfolios of achievement. Curtin University, for example, introduced the Curtin Extra Certificate in 2014 where students record their participation in approved extra-curricular activities to share with prospective employers and support applications for further study (Curtin University, 2016). Indeed, extra-curricular activities are becoming less 'optional' and more 'mandatory' for some graduates to succeed in competitive labour markets.

Student unions are responsible for representing the interests of students, communicating student views to university management, and providing extra-curricular opportunities through clubs and societies. There has been little research on the role of student unions in Australia, compared to the United Kingdom and United States. Although the structures and operations of student-led organisations differ within and across the three nations, the main role of these organisations is to represent students and advocate for their rights and interests. Research from the United Kingdom found that student unions have a range of important functions, including: representing students; providing services; improving the student experience; providing welfare services; campaigning; supporting students; running social events; running student societies; and promoting equality and diversity (Brooks, Byford \& Sela, 2015b).

Being involved in student union activities can signal desirable employability skills to potential employers. Students can hold a variety of leadership positions within student unions, and research shows that extra-curricular activities that demonstrate leadership, responsibility, commitment, and accomplishment are especially desirable to employers (Rivera, 2011; Stuart 
et al., 2011). Participation in student union clubs and societies can also be a useful indicator of communication skills and personal qualities, and research suggests that social networks made through clubs and societies can help graduates find jobs and progress in their careers (Stuart et al., 2011).

Not all students have the same level of involvement with student unions. Studies from the United Kingdom have found that some student groups are under-represented in leadership and officer positions within student unions, including: black and minority ethnic (BME) students; mature age students, particularly those over 30 years of age; and female students, who are particularly under-represented in the role of president (Brooks et al., 2015a; Equality Challenge Unit, 2007). International research has also shown that low SES students spend less time than their peers participating in extra-curricular activities, including student-led clubs and societies (Martin, 2012; Walpole, 2013; Radloff, 2010; Stuart et al., 2011). This trend has been attributed to higher SES students having increased access to leisure time, as well as a 'privilege of ease' in navigating campus life due to accumulated social and cultural capital (Martin, 2012). International research has also suggests that ethnic minority students and mature age students are less likely to participate in student union activities (Stuart et al., 2011).

As described above, there is a growing focus on improving student employability in contemporary higher education. To date, little attention has been given to student voice and influence in the employability arena and the specific role of student unions has been largely ignored. To address this gap, a desktop review of student union structures and activities was conducted, followed by a national survey of student union representatives.

\section{Method}

Ethics approval was obtained from the La Trobe University Human Ethics Committee (E16016). A desktop review of student union structures and activities was conducted to explore the role of student unions in improving student employability. The review identified 43 separate unions, associations, and guilds for undergraduate students, across the 37 Australian public universities. Examined specifically were the types of positions available to students within student unions and their main areas of responsibility.

Student union representatives were surveyed to capture their perspectives on employability in higher education and explore the role of student unions. The survey comprised 33 questions and was administered via the Qualtrics online survey tool. Some survey questions asked for specific information about student union structures and activities, while other survey questions asked for responses based on personal experiences and perceptions. A total of 164 student representatives across all Australian public universities were invited to participate in August 2016. The invitation database covered all 37 public universities and included the 43 different student unions identified via the desktop review. Invitations were extended to presidents, vicepresidents, general secretaries, and equity officers. The term 'student representatives' is used to collectively refer to students holding these positions within student unions. A total of 54 out of 164 student representatives responded to the survey, representing a 33 per cent response rate overall. Survey respondents included representatives from 31 out of the 43 student organisations identified in the desktop review (72 per cent). Survey respondents came from all university types, including technology focussed; research-intensive (known as the 'Group of Eight'); innovative research; and regional universities.

\section{Findings}

From the desktop review and national survey, five broad ways in which student unions can increase student employability were identified: providing input into university employability strategies; placing students in positions of leadership and responsibility; delivering careers services; managing clubs and societies; and advocating for students from equity groups who have relatively poor completion rates and/or graduate outcomes. 
Student unions are an important avenue through which students can have input into university employability strategies and initiatives. The survey found that a little over one third (38 per cent) of universities had a formal employability strategy for students. Only four out of the 31 student unions (13 per cent), however, had provided input into the student employability strategy at their university. These student unions provided input by having student representatives sit on, and actively participate in, various boards and committees that guide the employability strategies. This input was provided at multiple levels, including: academic board; education committees; student experience committees; teaching and learning committees; and faculty level teaching and learning boards. While few student unions had input into employability strategies, approximately three quarters of the students (74 per cent) thought that student unions should seek to influence university employability strategies.

The survey also found that student representatives had strong but mixed views about the extent to which universities should prioritise student employability. Overall, however, student representatives were more likely to think that employability should be prioritised over broader learning (see Table 1).

Table 1: Should Higher Education Prioritise Improving Student Employability or Promoting Learning and Knowledge More Broadly?

\begin{tabular}{lcc}
\hline Response & $\begin{array}{l}\text { Count } \\
\text { of students } \\
(\mathbf{n = 4 5 )}\end{array}$ & $\begin{array}{c}\text { Proportion } \\
\text { of students } \\
\%\end{array}$ \\
\hline Prioritise employability & 18 & 40 \\
\hline Focus equally on the two objectives & 17 & 37 \\
\hline Prioritise broader learning & 10 & 23 \\
\hline
\end{tabular}

A relatively high proportion of student representatives (40 per cent) felt that employability should be prioritised over broader learning. These students felt that an employability focus was necessary in contemporary higher education given the current economic climate and labour market trends. As one student commented:

With the increasing cost of university degrees and the proliferation of graduates who cannot find work in their field, I think it is fair that more attention is placed on employability now.

In contrast, approximately one quarter of student representatives (23 per cent) felt that universities should prioritise broader learning over employability. These students felt that higher education should focus on developing student knowledge, intellectual curiosity, critical analysis, and independent thought. Several students felt that university provided a unique opportunity for the pursuit of learning for its own sake, whereas employability skills could be gained outside of university study. One student, for example, thought that:

Universities should be focussed on teaching students their subject matter of their degree. It is an employer's responsibility to train them for the job.

Slightly more than one third of the student representatives (37 per cent) felt that universities should be equally focussed on improving employability and broader learning. These students tended to view the two objectives being integrated and complementary. One student, for example, commented as follows:

I don't think they're mutually exclusive. Developing learning capabilities and intellectual rigor should improve a student's use as a potential employee. Focusing 
purely on practical skills may make them more job ready, but less flexible and adaptable.

Some student representatives specified that, while both objectives were equally important, professional degrees should have an employability focus and generalist programs should have a broader educational focus. Other student representatives emphasised the importance of providing students with choice to meet their various needs. One student, for example stated that:

Students who wish to come to university solely for the purpose of finding a job should be catered for. Similarly, I believe students who are there to learn more skills, critical thinking techniques, and knowledge in general should also be encouraged and nurtured.

\section{Positions of leadership and responsibility}

Unions provide students with the opportunity to hold a variety of positions of leadership and responsibility that can improve their employability. The desktop review found that every student union (100 per cent) had a president and vice-president, who were typically elected by fellow students. Students in leadership positions could learn high level governance and organisational management which were seen to be particularly transferable to employment. These positions had a high level of responsibility for representing students and communicating student views to university administration. Unions were described by several student representatives as providing a relatively safe and accessible environment for students to develop employability skills. One student, for example, described these situations as a:

...typically risk-reduced introduction to small to medium sized organisations that students otherwise need to [go to] work or go on an internship to receive. The responsibility and experience is rarely found in other activities a student typically engages in.

Students could also manage clubs and societies where they learned transferable skills of financial management, basic governance, and people management.

Three quarters of the student unions (74 per cent) recruited students as paid office bearers and almost half ( 45 per cent) of the student unions recruited students as unpaid office bearers. The desktop review revealed that many of these officer positions were structured around particular areas of responsibility or specific student groups. Some of the more common positions with particular areas of responsibility: welfare officers (present in 49 per cent of student unions); social engagement officers (42 per cent), and environmental officers (40 per cent). The most common positions associated with specific student groups were: women's officers (42 per percent); and LGBTIQ officers (lesbian, gay, bisexual, transgender, intersex, queer, or questioning) (40 per cent).

The majority of student unions (71 per cent) also recruited students as volunteers. Volunteering was seen as a major aspect of unions where students could learn about teamwork and event coordination, make social connections, and receive positive job references. As one student explained:

... a good volunteer can get a great reference from the student union and also have the opportunity to network with so many different students and potentially staff.

Almost half (48 per cent) of the unions employed students as causal workers. Students employed as casuals, such as hospitality and service staff, often received training and obtained professional experience relevant to their specific duties. Some short courses were provided (or discounted) through some student unions, such as Responsible Service of Alcohol, Microsoft Office Excel, General Construction Instruction, and First Aid. 
Student unions provide students with the opportunity to participate in a range of clubs and societies which can be cultural, political, spiritual, musical, sport, special interest, and discipline-related. The desktop review identified 2,890 different clubs and societies across 43 student unions. Student representatives often commented on the diversity of clubs and societies on offer, many of which centred on different student groups. There were groups for LGBTIQ, Indigenous, Muslim, Indonesian, Papua New Guinea (PNG), and Pacific Islander students, for example, among many others. As one student testified:

Keeping a diverse range of clubs and societies means that the most students can be involved.

Many clubs and societies were free or had low cost memberships so that cost was a negligible barrier to entry.

Student representatives were asked for their views on how participation in clubs and societies can improve employability. Participating in clubs and societies was seen to help develop transferable skills for future employment. Four types of skills were identified most frequently: management and governance; event organisation; leadership; general planning and organisation (see Table 2). As one student summarised, 'Clubs and societies offer students a chance to act as a leader of an organisation, manage its finances, and coordinate its activities. Additionally, clubs and societies thrive off delegation and teamwork, which are invaluable soft skills'.

Table 2: How Does Participating in Student Union Clubs and Societies Improve Employability?

\begin{tabular}{lcc}
\hline Skills developed & $\begin{array}{c}\text { Count } \\
\text { of student } \\
\text { representatives } \\
(\mathbf{n}=\mathbf{4 9 )}\end{array}$ & $\begin{array}{c}\text { Proportion } \\
\text { of student } \\
\text { representatives } \\
\%\end{array}$ \\
\hline Management and governance & 10 & 20 \\
\hline Event organisation & 10 & 20 \\
\hline Leadership & 9 & 18 \\
\hline General planning and organisation & 9 & 18 \\
\hline Social and networking & 6 & 12 \\
\hline Teamwork & 5 & 10 \\
\hline Communication & 4 & 8 \\
\hline
\end{tabular}

Participating in clubs and societies was seen to offer broader benefits beyond the development of employability skills. The social benefits of participation were seen to contribute to a positive student experience as well as helping to secure employment after graduation. As one student representative noted:

...the basic provision of a social network and peer group can improve a student's morale and marks during university whilst providing networking links with associated job prospects after graduation.

The fact that participation was viewed favourably by potential employers was also noted. One student, for example, explained that:

Students gain a wealth of experience that is above and beyond their competitors when they demonstrate they have a passion for their hobbies and are willing to develop their 
experiences. The job market is increasingly giving weight to these types of experiences

on the CV.

Some clubs also maintained an alumni record that provided students with a positive job reference to help them enter the workforce.

\section{Provision of careers services}

Student unions can potentially increase employability through the provision of their own careers services and by referring students to centralised careers services. However, when asked whether their student union directly provided careers services, only four out of 31 surveyed student unions (13 per cent) reported that they provided job interview training, curriculum vitae (CV) checks, and careers information, and organised employer networking events. The survey also found that there was little interaction between student unions and careers services. Only approximately one third of student unions (35 per cent) directly interacted with careers services at their university. This interaction was typically minimal and included: cross-promotion of employment opportunities, including advertising student union positions through careers services; some direct referrals between student unions and careers services; and organising joint volunteering and leadership programs and other events. While the unions rarely provided their own careers services, three quarters of the student representatives (76 per cent) felt that unions should directly provide at least some basic careers services, such as advice about CVs, job applications, and job interviews. There were several barriers limiting the capacity for student unions to provide their own careers services, however, especially a lack of funding for suitably trained staff (see Table 3).

Table 3: What are the Main Barriers to Student Unions providing Careers Services?

\begin{tabular}{lcc}
\hline Main barriers & $\begin{array}{c}\text { Count } \\
\text { of student } \\
\text { representatives } \\
\text { (n= 36) }\end{array}$ & $\begin{array}{c}\text { Proportion } \\
\text { of student } \\
\text { representatives } \\
\%\end{array}$ \\
\hline $\begin{array}{l}\text { Lack of funding to recruit/train staff to deliver } \\
\text { careers services }\end{array}$ & 17 & 47 \\
\hline $\begin{array}{l}\text { Lack of demand due to centralised careers } \\
\text { services and/or small campus sizes }\end{array}$ & 11 & 31 \\
\hline $\begin{array}{l}\text { Lack of funding for additional expenses e.g. set } \\
\text { up costs, infrastructure, industry connections }\end{array}$ & 9 & 14 \\
\hline $\begin{array}{l}\text { Difficult to coordinate and integrate within the } \\
\text { organisational structure of the university }\end{array}$ & 5 & \\
\hline
\end{tabular}

Advocating for equity groups who have relatively poor completion rates and/or graduate outcomes

Student representatives expressed concern about the employability of students from equity groups and felt that universities were not doing enough to address inequalities in completion rates and graduate outcomes. Only seven student representatives (16 per cent) felt that their universities were promoting the employability of students from equity groups either 'very well' or 'extremely well'. These students offered a range of recommendations to address this gap, many of which involved universities collaborating more closely with employers. The most common recommendations were to: develop placements and internships targeted to equity groups; and organise more employer networking events, careers fairs, and professional mentoring opportunities. Students also recommended that universities provide: increased 
access to extra-curricular opportunities for equity students; greater integration of employability into compulsory units; and more careers advisors with a direct focus on equity groups.

More broadly, student representatives were concerned that some employers had recruitment practices that disadvantaged equity groups. Based on their personal experiences and perceptions, survey respondents indicated which equity groups they thought found it easier, the same, or more difficult than their peers to secure employment after graduation. The majority of student representatives (80 per cent) reported that graduates from non-English speaking backgrounds find it more difficult than their peers to secure employment. This trend was often attributed to employer discrimination. As one student commented:

All too often a student/graduate is overlooked due to cultural background, accent, name etc without being given a chance.

Approximately two-thirds of survey respondents (66 per cent) reported that graduates with a disability find it more difficult than their peers to secure employment. As one student noted:

The additional requirements for successfully hiring a person with a disability can scare potential employers.

Approximately two-thirds of survey respondents (64 per cent) reported that graduates from low SES backgrounds find it more difficult than their peers to secure employment. Low SES graduates were also seen to be unfairly disadvantaged due to smaller professional networks. One student explained that:

People with more connections and greater opportunities to network and greater financial backing always have an advantage when there is no equity in a system.

Student representatives reported that universities did not customarily provide student unions with data that could help them support equity groups. One student stated that:

The university does not provide the [student union] with any statistics in relation to retention of students from these areas. It would be helpful to have access to this information so that the [student union] could support students identified as most at risk.

Furthermore, student unions themselves did not routinely collect data on the extent of equity group involvement in union activities. Fewer than half of the student unions monitored how many of their position holders were from equity groups. Only two of the 31 surveyed student unions (six per cent) monitored how many students from any of the equity groups participated in clubs and societies.

Student representatives were troubled by inequalities in extra-curricular participation and the potential effect on employment outcomes. Based on their personal experiences and perceptions, survey respondents indicated which groups they thought were less likely than their peers to participate in extra-curricular activities. The majority of student representatives (74 per cent) reported that low SES students were less likely than their peers to participate in these extra-curricular activities that might increase their employability, such as volunteering, work experience, and overseas exchange programs. This trend was attributed to a lack of available time and financial resources, often linked with the need to prioritise paid work. As one student explained:

Working combined with university commitments, family commitments, and a need for social interaction don't really afford students the time or money to volunteer or go overseas.

Approximately two thirds of student representatives (65 per cent) reported that students with a disability were also less likely to participate in extra-curricular activities. The trend was attributed to social barriers, especially fears of exclusion and discrimination, and physical limitations, depending on the nature and extent of disability. Despite these trends, universities did not consistently provide support to encourage equal extra-curricular participation. The 
most common types of support were targeted bursaries for students in financial hardship to participate in work placements and/or overseas exchange programs, which were provided by 40 per cent of universities.

\section{Discussion and implications}

The findings underlined the important role that student unions can play in improving student employability, but also revealed a range of limitations. Five broad ways in which student unions can increase student employability were identified: providing input into university employability strategies; placing students in positions of leadership and responsibility; delivering careers services; managing clubs and societies; and advocating for students from equity groups who have relatively poor completion rates and/or graduate outcomes. Some of these approaches were widespread, while others were only provided by a minority of student unions. Taken together, these findings help to fill the gap in the employability literature regarding the influence of student voice and the role of student unions.

Student unions routinely provided opportunities to improve employability beyond degree study. All student unions placed students in positions of leadership and responsibility and managed a range of clubs and societies. Consistent with previous research, the student representatives recognised that leadership experience was especially desirable to employers, and that participation in clubs and societies was associated with improved social networks and transferable skills (Rivera, 2011; Stuart et al., 2011). Few student unions provided their own careers services, however, often attributed to funding constraints. Direct interaction between student unions and centralised careers services was also minimal.

Despite being keen to contribute to the development of employability strategies, students were mostly marginalised from institutional processes. Only a small minority of student unions provided input into the student employability strategies at their universities, yet most students thought that their unions should have this input. Indeed, student representatives had strong views about the prioritisation of employability in higher education. While many felt that improving student employability should be a university priority, they were also mindful of the need to balance this objective with broader learning for its own sake. Student representatives were also concerned about the employability of students from equity groups, particularly graduates from non-English speaking backgrounds and graduates with a disability, and felt that universities could do more in this space. These concerns are in line with previous research that has documented the particularly poor outcomes of graduates from non-English speaking backgrounds and graduates with a disability (Brett, 2016; Graduate Careers Australia [GCA], 2015; Li et al., 2016; Mestan \& Harvey, 2014).

Student representatives reported that universities did not provide their unions with institutional equity data. Furthermore, student unions themselves did not routinely collect data on the extent of equity group involvement in student union positions and activities, often because of a lack of access to institutional data. This lack of data limits the ability to examine whether student unions are adequately catering to diverse student populations. International research has found that black and minority ethnic (BME) students in the UK, mature age students, and women are less likely than others to take up student union positions (Brooks et al., 2015a; Equality Challenge Unit, 2007). Furthermore, low SES students, ethnic minority students, and mature age students can be less likely to participate in clubs and societies (Martin, 2012; Walpole, 2013; Stuart et al., 2011). Equivalent research is needed to determine if these concerning disparities are mirrored in Australia.

It is worth noting a limitation of the project. The research would have been aided by full participation in the survey across all 43 student unions identified in the desktop review. While responses were obtained from 31 of the 43 student unions (72 per cent), which represents a healthy sample, it is not possible to draw any specific conclusions about the student unions that did not respond to the survey. The desktop review, however, covered the 43 student unions which allowed their structures and activities to be examined. 
This research has implications for both universities and student unions. Universities and unions could work more collaboratively to ensure there is more student input into the design, implementation, and evaluation of employability strategies. For example, universities could ensure student equity is considered more prominently when forging stronger links with potential employers. There is also a need for further integration of employability into mainstream curricula, so that students who cannot participate in extra-curricular activities are not disadvantaged. Both universities and student unions could collect and share more equity data to better monitor and support equity groups. Student unions could form tighter links with careers services and direct referrals between these two areas could be promoted.

More broadly, this research highlights the need for cultural change to redress unequal graduate outcomes. This change will require greater collaboration between universities, students, and employers to address underlying issues such as unconscious bias and discrimination. As employability is central to the modern mission of higher education, student unions have an increasingly important role to play in supporting a diverse student population into rewarding and sustained employment.

\section{Acknowledgements}

The authors wish to acknowledge the general advice given by: Dr Daniel Edwards, Principal Research Fellow, Australian Council for Educational Research; Professor Julia Clarke, ProVice Chancellor and Dean of Faculty of Business and Law, Manchester Metropolitan University; and Kimberly Reyes, Center for the Study of Higher and Postsecondary Education, University of Michigan.

\section{Funding}

This article draws on selected findings from a research project funded by the Australian Government Department of Education and Training through the Higher Education Participation and Partnerships Program - National Priorities Pool 2015. 


\section{References}

Australian Government. (2017). Higher education reform package. Retrieved 12 May from https://www.education.gov.au/higher-education-reform-package-0

Bennett, D., Richardson. S., \& MacKinnon, P., (2016). Enacting strategies for graduate employability: How universities can best support students to develop generic skill. Part

A. Canberra, ACT: Australian Government, Office for Learning and Teaching, Department of Education and Training.

Brett, M. (2016). Disability and Australian higher education: Policy drivers for increasing participation. In A. Harvey, C. Burnheim, \& M. Brett (Eds.), Student equity in Australian higher education: Twenty-five years of A Fair Chance for All (pp. 86-108). Singapore: Springer Publishing.

Bridgstock, R. (2009). The graduate attributes we've overlooked: Enhancing graduate employability through career management skills. Higher Education Research and Development, 28(1), 31-44. doi: 10.1080/07294360802444347

Brooks, R., Byford, K., \& Sela, K. (2015a). Inequalities in students' union leadership: the role of social networks, Journal of Youth Studies, 18(9), 1204-1218. doi: 10.1080/13676261.2015.1039971

Brooks, R., Byford, K., \& Sela, K. (2015b). The changing role of students' unions within contemporary higher education. Journal of Education Policy, 30(2), 165-181. doi: $10.1080 / 02680939.2014 .924562$

Burnheim, C., \& Harvey, A. (2016). Far from the studying crowd? Regional and rural Australians in higher education. A. Harvey, C. Burnheim and M. Brett (Eds), Student Equity in Australian Higher Education: Twenty-five Years of A Fair Chance for All (pp. 143-162). Singapore: Springer Publishing.

Centre for the Study of Higher Education. (2008). Participation and equity: A review of the participation in higher education of people from lower socioeconomic backgrounds and Indigenous people. Melbourne, Australia: Universities Australia and the Centre for the Study of Higher Education, University of Melbourne.

Curtin University. (2016). Curtin Extra Certificate. Retrieved 15 May 2017 from https://graduations.curtin.edu.au/graduate/curtinExtra faq.cfm

Department of Education Employment and Training (DEET). (1990). A Fair Chance for All: National and institutional planning for equity in higher education. Canberra: Australian Government Publishing Service.

Edwards, D., \& Coates, H. (2011). Monitoring the pathways and outcomes of people from disadvantaged backgrounds and graduate groups. Higher Education Research and Development, 30(2), 151-163. doi: 10.1080/07294360.2010.512628

Equality Challenge Unit (ECU). (2007). Inclusive students' unions: Survey findings 2007. London: ECU.

Graduate Careers Australia (GCA). (2015). Graduate destinations 2014: A report on the work and study outcomes of recent higher education graduates. Melbourne: Graduate Careers Australia Ltd.

Harvey, A., \& Andrewartha, L. (2013). Dr Who? Equity and diversity among university postgraduate and higher degree cohorts. Journal of Higher Education Policy and Management, 35(2), 112-123. doi: 10.1080/1360080X.2013.775921

Harvey, A., Andrewartha, L., Edwards, D., Clarke, J., \& Reyes, K. (2017). Student equity and employability in higher education. Report for the Australian Government Department of Education and Training. Melbourne: Centre for Higher Education Equity and Diversity Research, La Trobe University.

Harvey, A., Burnheim, C., \& Brett, M. (2016). Towards a fairer chance for all: Revising the Australian student equity framework. In A. Harvey, C. Burnheim, \& M. Brett (Eds.), Student equity in Australian higher education: Twenty-five years of A Fair Chance for All (pp.3-20). Singapore: Springer Publishing. 
Li, I. W., Mahuteau, S., Dockery, A., M., Junankar, P. N., \& Mavromaras, K. (2016). Labour market outcomes of Australian university graduates from equity groups. Perth, WA: National Centre for Student Equity in Higher Education (NCSEHE) at Curtin University.

Martin, N. D. (2012). The privilege of ease: Social class and campus life at highly selective, private universities. Research in Higher Education, 53, 426-452. doi: 10.1007/s11162011-9234-3

Messum, D., Wilkes, L., Peters, K., \& Jackson, D. (2016). Content analysis of vacancy advertisements for employability skills: Challenges and opportunities for informing curriculum development. Journal of Teaching and Learning for Graduate Employability, 6(1), 72-86.

Mestan, K., \& Harvey, A. (2014). The higher education continuum: Access, achievement and outcomes among students from non-English speaking backgrounds. Higher Education Review, 46(2), 61-79.

Quality Indicators for Teaching and Learning (QILT). (2017). Quality Indicators for Teaching and Learning. Retrieved 12 May 2017 from https://www.qilt.edu.au/

Radloff, A. (2010). Doing more for learning: Enhancing engagement and outcomes. Australasian Survey of Student Engagement: Australian student engagement report. Camberwell: Australian Council for Educational Research (ACER).

Richardson, S., Bennett, D., Roberts, L. (2016). Investigating the relationship between equity and graduate outcomes in Australia. Perth, WA: National Centre for Student Equity in Higher Education at Curtin University.

Rivera, L. A. (2011). Ivies, extracurricular, and exclusion: Elite employers' use of educational credentials. Research in Social Stratification and Mobility, 29(1), 71-90. doi: 10.1016/j.rssm.2010.12.001

Stuart, M., Lido, C., Morgan, J., Solomon, L., May, S. (2011). The impact of engagement with extracurricular activities on the student experience and graduate outcomes for widening participation populations. Active Learning in Higher Education, 12(3), 203215. doi: $10.1177 / 1469787411415081$

Tran, T. T. (2016). Enhancing graduate employability and the need for university-enterprise collaboration. Journal of Teaching and Learning in Graduate Employability, 7(1), 58-71.

Walpole, M. (2003). Socioeconomic status and college: How SES affects college experiences and outcomes. The Review of Higher Education, 27(1), 45-73.

Yorke, M. (2006). Employability in higher education: what it is - what it is not. Learning \& Employability Series One. York: The Higher Education Academy. 